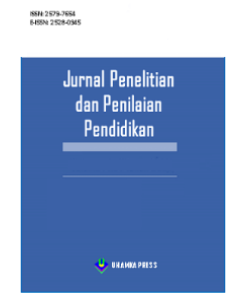

Jurnal Penelitian dan Penilaian Pendidikan

ISSN:2579-7654 (Online) 2528-0945 (Print)

Journal Homepage: https://journal.uhamka.ac.id/index.php/jppp

\title{
MODEL DISCOVERY LEARNING PADA PERLINDUNGAN DAN PENEGAKAN HUKUM DAPAT MENINGKATKAN HASIL BELAJAR SISWA KELAS XII
}

\section{Sri Wahyuningsih}

How to cite : Wahyuningsih, Sri., 2021. MODEL DISCOVERY LEARNING PADA PERLINDUNGAN DAN PENEGAKAN HUKUM DAPAT MENINGKATKAN HASIL BELAJAR SISWA KELAS XII. Jurnal Penelitian dan Penilaian Pendidikan. 3(1). 29-36.

To link to this article : https://doi.org/10.22236/jppp.v3i1.5911

C2021. The Author(s). This open access article is distributed under a Creative Commons Attribution (CC BY-SA) 4.0 license.

Published Online on 12 Desember 2020

https://journal.uhamka.ac.id/index.php/jppp

View Crossmark data 


\title{
MODEL DISCOVERY LEARNING PADA PERLINDUNGAN DAN PENEGAKAN HUKUM DAPAT MENINGKATKAN HASIL BELAJAR SISWA KELAS XII
}

\author{
Sri Wahyuningsih ${ }^{1}$ \\ ${ }^{1}$ Universitas Muhammadiyah Prof DR HAMKA \\ E-mail: $\quad$ sri.wahyuningsih@uhamka.ac.id ${ }^{1)}$
}

Received: 4 October 2020/Accepted: 1 Desember 2020/ Published Online: 12 Desember 2020

\begin{abstract}
Abstrak
Penelitian ini diawali dengan adanya kebosanan siswa dalam belajar yangmengakibatkan nilai hasil belajar rendah, maka dilakukan terobosan baru belajar dengan menggunakan model pembelajaran discovery learning, tujuannya adalah meningkatkan hasil belajar siswa. Model ini menerapkan pemecahan masalah dari tugas yang di sampaikan oleh gurumelalui bentuk karya film pendek berupa video yang diperankan oleh siswa dengan kelompoknya. Penelitian dilakukan dengan 3 siklus yaitu siklus pertama berupa pembuatan narasi kelompok, siklus kedua pemeranan dalam tayangan video, siklus tiga tehnik sederhana pembuatan video tersebut. Hasil tes pengetahuan pada siklus pertama adalah 77.97 siklus kedua 82.80 dan siklus ketiga 89.00 sementara hasil pengamatan siklus pertama 83.20 siklus kedua 86.68 dan siklus ketiga 88.33 .
\end{abstract}

Kata Kunci : Hasil belajar, Model Discovery Learning, Perlindungan dan Penegakan Hukum.

\begin{abstract}
This research began with students' boredom in learning which resulted in low learning outcomes, so a new learning breakthrough was carried out using the discovery learning model, the aim was to improve student learning outcomes. This model applies problem solving to assignments conveyed by the teacher through the form of short films in the form of videos played by students and their groups The research was carried out in 3 cycles, namely the first cycle in the form of making group narratives, the second cycle acting in video shows, the three cycles of simple video making techniques. The results of the knowledge test in the first cycle were 77.97 , the second cycle was 82.80 and the third cycle was 89.00 while the results of the observations of the first cycle were 83.20 , the second cycle was 86.68 and the third cycle was 88.33 .
\end{abstract}

Keywords: Discovery Learning Model, Learning outcomes, Protection and Law Enforcement.

This is an open access article under the Creative Commons Attribution 4.0 International License 
1. PENDAHULUAN

Saat ini di Sekolah Menengah Kejuruan Negeri 11 Jakarta khusus pada mata diklat PKn kembali mencoba mengadakan sebuah penelitian tindakan kelas dan penelitian itu dilakukan pada siswa kelas XII AKL 2, penyebab di pilihnya kelas tersebut karena dari 12 kelas yang di bimbing hanya 1 kelas yaitu kelas XIIAKL2 yang nilai hasil ulangannya rendah, rendahnya nilai yang mereka peroleh karena ada kebosanan terhadap cara belajar. Untuk merubah hasil belajar maka dicobalah model pembelajaran discovery learning, pada model ini siswa dipacu untuk aktif dalam memecahkan masalah, ada diskusi di dalamnya sehingga disamping memperoleh nilai kelompok siswa juga mendapat nilai pribadi yang akan diperoleh setelah menyelesaikan tugas. Perumusan masalah pada penelitian ini adalah bagaimana penerapan model discovery learning dapat meningkatkanhasil belajar perlindungan dan penegakan hukum siswa kelas XII AKL 2 SMKN 11 Jakarta tahun 2019. Adapun tujuan penelitian ini adalah untuk mengetahui bagaimana penerapan model discovery learning dapat meningkatkan hasil belajar perlindungan dan penegakan hukum siswa kelas XII AKL2 SMKN 11 Jakarta tahun 2019.

\section{METODE PENELITIAN}

Penelitian dilakukan di SMK Negeri 11 Jakarta pada kelas XII AKL 2 dan dilaksanakanpada semester genap tahun 2019/2020. Populasi dan Sampel Penelitian adalah siswa kelasXII AKL2 terdiri dari 36 siswa yang ikut dalam bimbingan pembelajaran semester genap untuk tahun pelajaran 2019/2020. Desain penelitian dilakukan melalui 4 tahap yaitu perencanaan, tindakan, pengamatan dan refleksi.

Dalam tahap perencanaan di atur tentang strategi pembelajaran model discovery learning dan stuktur pengelolaan pembelajarannya, kemudian jenis media yang dapat diterapkan, aspek-aspek yang terkait dengan cara mengajar,substansi materi yang disampaikan dan tehnik penilaian yang digunakan. Setelah permasalahan diidentifikasi, maka ditentukan tindakan yang berkaitan dengan model discovery learning yaitu mengembangkan dan menerapkan model discovery learning pada mata pelajaran PKn.Tahap tindakan dilakukan dengan 3 siklus, siklus pertama berupa pemberianstimulasi, problem statemen, data colecting, data procesing,verification danGeneralization.

$\triangle$ Sri Wahyuningsih

sri.wahyuningsih@gmail.com

${ }^{1}$ Sekolah Menengah Kejuruan Negeri 11 Jakarta 
Dalam tahapan pertama ditayangkan video singkat tentang praktek perlindungan dan penegakan hukum dari you tube, pemilihan topik kajian untuk model discovery learning yang disesuiakan dengan kompetensi dasar, kemudian di buat rancangan garis besar pelaksanaan pembelajaran model discovery learning pada mata pelajaran PKn dengan kompetensi dasar praktek perlindungan dan penegakan hukum. Menentukan bagian-bagian materi yang harus dibuat siswa, misal praktek dalam bidang sosial, ekonomi, agama dan bidang budaya.

Kemudian membagi kelas dalam kelompok kecil ,menentukan ketua koordinator pembuatan video, menentukan materi yang akan dipilih, menentukan tokoh atau pemeran, membuat dialog skript, menentukan tempat atau daerah pembuatan video ,menentukan batas jadwal pembuatan, jadwal pemeriksaan dan dan batas penyerahan video, serta mempersiapkan sarana yang perlukan. Pada siklus kedua dijelaskan tentang tujuan pembuatan video, melakukan pembuatan video diluar jam pelajaran, menjelaskan garis besar materi pelajaran praktek perlindungan dan penegakan hukum.siklus ketiga mempersilahkan siswa melakukan penayangan dari hasil video yangdi buatnya, sementara kelompok lain mengkritisi penayangan video tersebut secara bergantian, kemudian dilakukan perbaikan bila hasil penayangan video kurang sesuai dan melakukan pelaporan hasil kerja pembuatan video dalam CD room.

Tahap ke tiga berupa pengamatan, yaitu meminta bantuan teman sejawat yang mengajar mata pelajaran yang sama untuk mengamati seluruh kegiatan siswa kelas XII AKL2 pada saat mengikuti pembelajaran PKn, tugas pengamat adalah mensupervisi dengan mencatat, merekam, mendokumentasikan. Proses pengumpulan data terfokuspada kemampuan siswa dalam melakukan kerjasama dengan kelompok dalam menentukan topik tayangan, menentukan visi dan misi tayangan ,menentukan tokoh atau pemeran, membuat skrip yang akan di tayangkan, menentukan tempat pelaksanaan, menyiapkan sarana dan prasarana, mengkritisi tayangan kelompok lain.

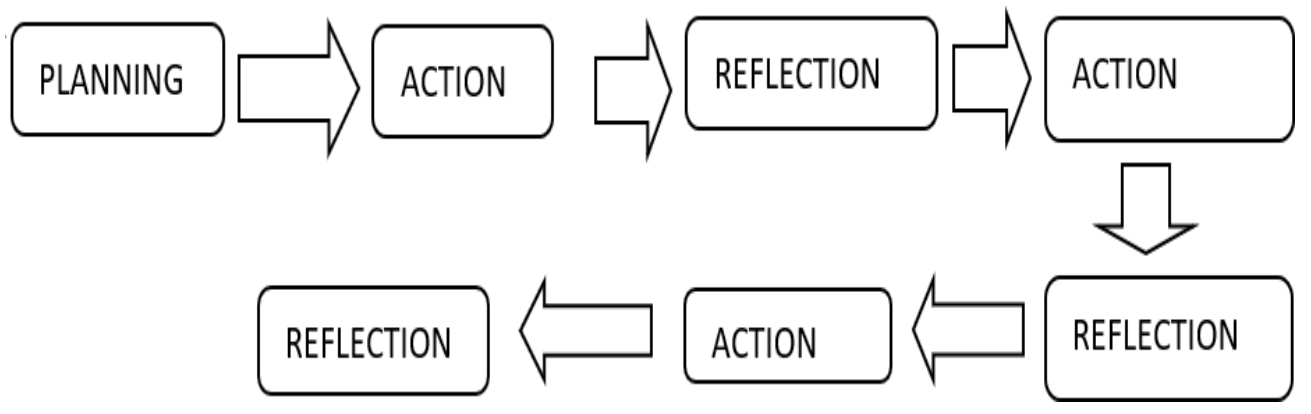


Model Discovery Learning pada Perlindungan...

Tahap terakhir adalah refleksi yaitu suatu tahapan yang dilakukan untuk mengevaluasi dampak penerapan model discovery learning pada kompetensi dasar praktek perlindungan dan penegakan hukum. Tingkat keberhasilan yang dicapai ditunjukan dengan data bahwa sebanyak $80 \%$ dari jumlah siswa dikelas mendapat nilai setara atau di atas KKM. Gambaran pada penelitian tindakan kelas ini dapat didesain sebagai berikut :

\section{Kinerja Penelitian}

Kinerja penelitian dilakukan selama tiga siklus. Proses berulangnya tindakan dalam setiap siklus ditentukan beberapa ketercapaian indikator antara lain $80 \%$ siswa memiliki antusias untuk menciptakan video karena pemerannya adalah mereka sendiri, menciptakan, menayangkan dan mengkritisi apakah yang telah di kerjakan sudah sesuai dengan visi yang di emban, apakah cerita dengan materi sudah sesuai, dan setiap video yang sudah selesai di buat ditayangkan di depan kelas, dikritisi kelompok lain untuk perbaikan videonya sebelum di serahkan pada guru. Dari hasil pelaksanaan pembuatan video setidaknya $80 \%$ siswa menguasai peranannya dan sesuai dengan materi yang di embannya Sebagian siswa sekitar $80 \%$ dari kelas penelitian mendapat nilai sesuai KKM atau diatasnya.

\section{HASIL DAN PEMBAHASAN}

Tabel 1. Hasil penelitian siklus 1

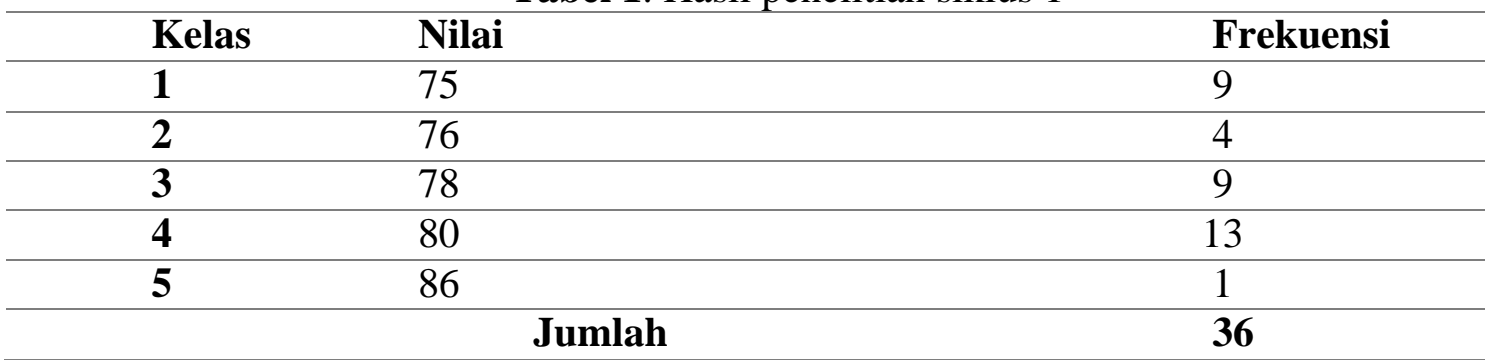

Dari data tersebut jika didiagram batangkan akan terlihat sebagai berikut :

Tabel 2. Diagram batang siklus 1

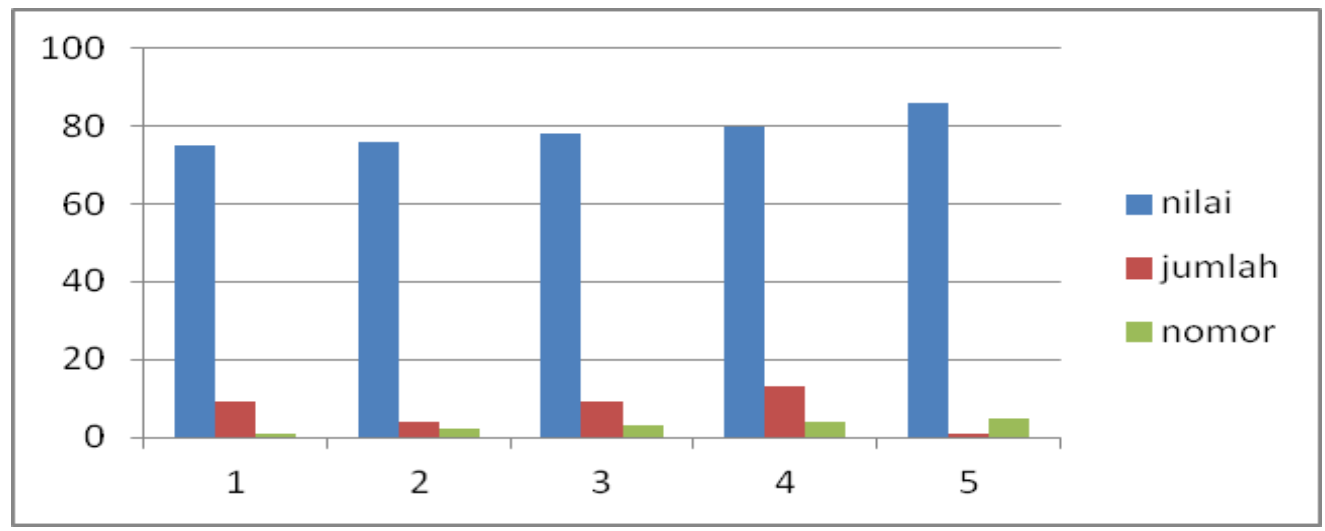


Dari hasil observasi selama proses tindakan, pada kompetensi dasar praktek perlindungan dan penegakan hukum mata pelajaran PKn di SMKN 11 Jakarta terlihat dalam tabel 2 dibawah ini :

Tabel 3. Data Hasil Pengamatan Siklus 1

\begin{tabular}{clc}
\hline No & \multicolumn{1}{c}{ Aspek } & Jumlah \\
\hline $\mathbf{1}$ & Penulisan skript & 108 \\
\hline $\mathbf{2}$ & Kesesuaian film dengan Kompetensi dasar & 144 \\
\hline $\mathbf{3}$ & Alur film & 108 \\
\hline $\mathbf{4}$ & Pengembangan alur film & 120 \\
\hline $\mathbf{5}$ & Realistis sesuai dengan perkembangan masyarakat & 132 \\
\hline & Skor Tertinggi Teoritik & 144 \\
\hline
\end{tabular}

Tabel 4. Hasil Tes Siklus Kedua Hasil Pengamatan Siklus 2

\begin{tabular}{ccc}
\hline Kelas & Nilai & Frekwensi \\
\hline $\mathbf{1}$ & 78 & 1 \\
$\mathbf{2}$ & 79 & 6 \\
\hline $\mathbf{3}$ & 80 & 7 \\
\hline $\mathbf{4}$ & 83 & 8 \\
\hline $\mathbf{5}$ & 85 & 12 \\
\hline $\mathbf{6}$ & 90 & 1 \\
\hline $\mathbf{7}$ & 95 & $\mathbf{3 6}$ \\
\hline
\end{tabular}

Dari data tersebut jika didiagram batangkan akan terlihat sebagai berikut :

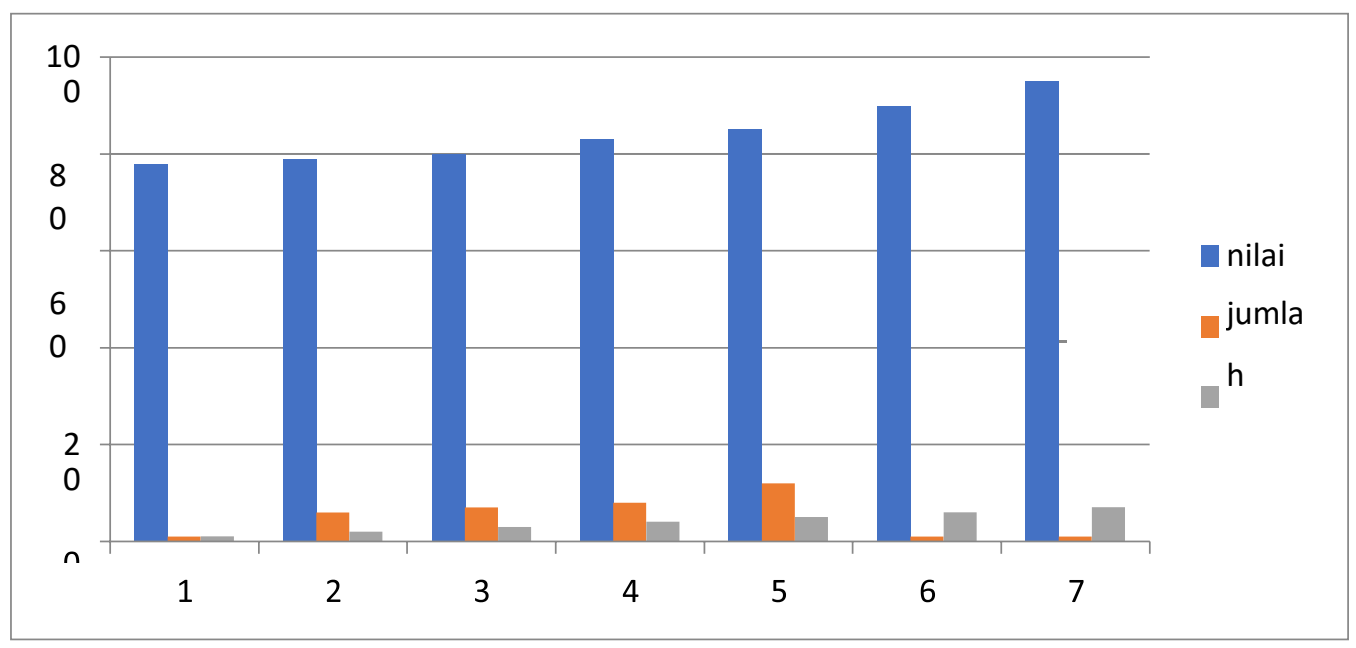

Dari hasil observasi selama proses tindakan, maka data tentang strategi pembelajaran dengan model discovery learning diterapkan pada mata pelajaran PKn di SMKN 11 Jakarta terlihat dalam tabel ini. 
Tabel 5. Data Hasil Pengamatan Siklus 2

\begin{tabular}{clc}
\hline No & \multicolumn{1}{c}{ Aspek } & Jumlah \\
\hline $\mathbf{1}$ & Kesesuaian tempat dengan alur film & 108 \\
\hline $\mathbf{2}$ & Penghayatan para pemeran film & 120 \\
\hline $\mathbf{3}$ & Amanah atau pesan yang di emban & 144 \\
\hline $\mathbf{4}$ & Kemampuan menjelaskan alur film & 144 \\
\hline $\mathbf{5}$ & Ketepatan waktu penyerahan tugas & 108 \\
\hline & Skor tertinggi teoritik & $\mathbf{1 4 4}$ \\
\hline
\end{tabular}

Tabel 6. Hasil Tes Siklus ke 3

\begin{tabular}{ccc}
\hline Kelas & Nilai & Frekwensi \\
\hline $\mathbf{1}$ & 87 & 12 \\
\hline $\mathbf{2}$ & 90 & 24 \\
\hline & Jumlah & $\mathbf{3 6}$ \\
\hline
\end{tabular}

Dari data tersebut jika didiagram batangkan akan terlihat sebagai berikut :

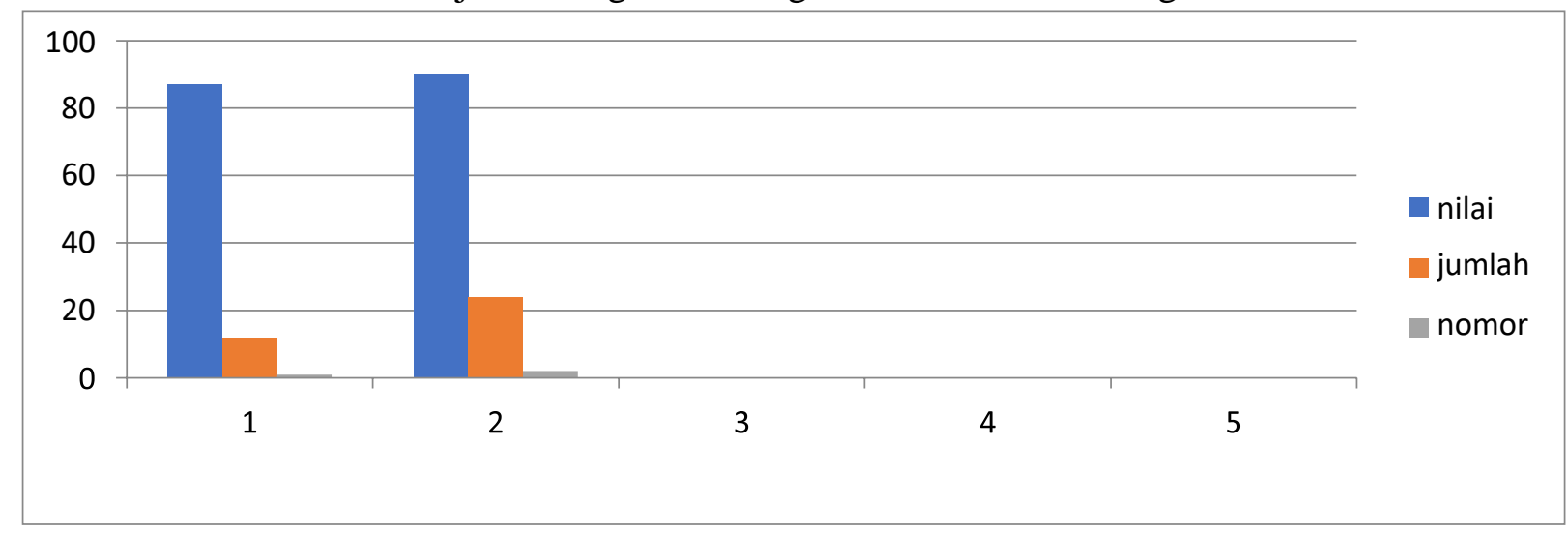

Dari hasil observasi selama proses tindakan terlihat dalam

Tabel 7. Data Hasil Pengamatan pada Siklus 3

\begin{tabular}{clc}
\hline No & \multicolumn{1}{c}{ Aspek } & Jumlah \\
\hline $\mathbf{1}$ & Ketertarikan penonton pada film & 132 \\
\hline $\mathbf{2}$ & Suara yang terdengar saat film di tayangkan & 132 \\
\hline $\mathbf{3}$ & Dialog antar pemain & 120 \\
\hline $\mathbf{4}$ & Penyusunan slide film & 108 \\
\hline $\mathbf{5}$ & Durasi & Skor tertinggi teoritik \\
\hline & & $\mathbf{1 4 4}$ \\
\hline
\end{tabular}

Hasil analisa data praktek perlindungan dan penegakan hukum melalui model discoverylearning di kelas XII AKL 2 adalah sebagai berikut : 
Data Hasil Tes Kompetensi Dasar

Tabel 7. Nilai rata-rata tes kompetensi

\begin{tabular}{cccc}
\hline \multirow{2}{*}{ Rata-rata } & Siklus 1 & Siklus 2 & Siklus 3 \\
\cline { 2 - 4 } & 77,97 & $\mathbf{8 2 , 8 0}$ & $\mathbf{8 9 , 0 0}$
\end{tabular}

Data hasil pengamatan model discovery learning dapat dilihat dalam

Tabel 8. Hasil Pengamatan Model discovery learning

\begin{tabular}{|c|c|c|c|c|}
\hline No & Aspek & Siklus 1 & Siklus 2 & Siklus 3 \\
\hline 1 & Penulisan skript & $75.00 \%$ & & \\
\hline 2 & $\begin{array}{l}\text { Kesesuaian film dengan Kompetensi } \\
\text { dasar }\end{array}$ & $100.00 \%$ & & \\
\hline 3 & Alur film & $75.00 \%$ & & \\
\hline 4 & Pengembangan alur film & $83.00 \%$ & & \\
\hline 5 & $\begin{array}{l}\text { Realistis sesuai dengan perkembangan } \\
\text { masyarakat }\end{array}$ & $83.00 \%$ & & \\
\hline 6 & Kesesuaian tempat dengan alur film & & $75.00 \%$ & \\
\hline 7 & Penghayatan para pemeran film & & $83.33 \%$ & \\
\hline 8 & Amanah atau pesan yang di emban & & $100,00 \%$ & \\
\hline 9 & Kemampuan menjelaskan alur film & & $100.00 \%$ & \\
\hline 10 & Ketepatan waktu penyerahan tugas & & $75.00 \%$ & \\
\hline 11 & Ketertarikan penonton pada film & & & $91.66 \%$ \\
\hline 12 & $\begin{array}{l}\text { Suara yang terdengar saat film di } \\
\text { tayangkan }\end{array}$ & & & $91.66 \%$ \\
\hline 13 & Dialog antar pemain & & & $83.33 \%$ \\
\hline 14 & Penyusunan slide film & & & $75 \%$ \\
\hline 15 & Durasi & & & $100 \%$ \\
\hline & Rata-rata & $83.20 \%$ & $86.68 \%$ & $88.33 \%$ \\
\hline
\end{tabular}

\section{KESIMPULAN}

Dari hasil temuan dan analisa di atas maka dapat disimpulkan bahwa : "Model Discovery Learning pada Perlindungan dan Penegakan Hukum dapat meningkatkan hasilbelajar siswa kelas XII AKL 2 SMKN 11 Tahun 2019”. Implikasinya merujuk pada hasil penelitian ini, maka penggunaan model Discovery Learning pada Perlindungan dan Penegakan Hukum dapat meningkatkan hasil belajar PKn siswa, oleh karenanya model ini dapat dijadikan 
model alternatif dan merupakan model pembelajaran yang menyenangkan, mudah dilaksanakan, bisa dipadukan dengan metode pembelajaran lain sesuai dengan kompetensi dasar. Perpaduan yang bervariasi menghasilkan karya baru, mengajar sambil mendidik bukan hal yang membosankan bila setiap guru mempunya konsep dan mampu memaknai arti dari model dan metode pembelajaan yang di gulirkanpemerintah.

\section{DAFTAR PUSTAKA}

Arikunto,Suharsimi.(1986) Dasar-dasar Evaluasi Pendidikan.Yogyakarta Bina Aksara.

Brady,L.( 1985) Models and Mathods of Teaching.Syidney:Prentice-hall of Australia.

Hamalik,Oemar,(1998) Pendekatan Baru Strategi Belajar Mengajar Berdasarkan CBSA,Bandung: Penerbit Sinar Baru

Surakhmad,W, (9186)Tehnik Interaksi Belajar-Belajar Mengajar, Jakarta:Jermars

Soekartawi. (1999) Meningkatkan Efektifitas Mengajar, Jakarta: PustakaJaya

Tim Lab PKn P4TK, (2009) Dasar - dasar Metodologi Pendidikan dalam Pendidikan

Tim Lab PKn P4TK, (2009) Sumber dan Media Pembelajaran Pendidikan Kewarganegaraan.

Tim Lab PKn P4TK, (2009) Penelitian Tindakan Kelas

Tim Lab PKn P4TK, (2009) Sisitim Penilaian Pembelajaran PKn

Tim Lab PKn P4TK, (2009) Pengembangan Bahan Ajar 